\title{
ECONOMETRIC ANALYSIS OF FOREIGN TRADE BETWEEN TURKEY AND CHINA WITHIN THE SCOPE OF INCOME AND PRICE ELASTICITIES
}

\author{
Mehmet Barıș ASLAN*
}

\begin{abstract}
The aim of the study is to analyze the income and price impact in trade between China and Turkey. In addition, to trade with this country which has a strategic importance in Turkey's foreign trade, to discuss the possible impact on Turkey's trade deficit. In the study where Autoregressive Distributed Lag (ARDL) econometric time series method was preferred, quarterly data of 1998Q1-2018Q4 period was used. All of the data were used in the analysis with their logarithmic values. The unit root test results performed showed that some variables are stationary in level values, while others contain unit roots. However, it has been observed that when the first differences are taken, they all become stable. F statistics obtained as a result of cointegration tests performed for both models showed that there is a long run integration relationship between variables. The results of long run coefficients showed that the impact of income in Turkey's exports to China is strong, stastically significant and compatible with economic expectations. On the other hand, both of price and income effects at Turkey's imports from China has been seen strong, istastically significant and compatible with economic expectations.
\end{abstract}

Keywords: Income and Price Elasticities, Foreign Trade, ARDL Boundary Test, China, Real Effective Exchange Rate.

* Dr. Öğr. Üyesi, Bingöl Üniversitesi, İktisadi ve İdari Bilimler Fakültesi, İktisat Bölümü, mbaslan@bingol.edu.tr, https://orcid.org/0000-0003-3783-4079 


\title{
TÜRKIYY İLE ÇIN ARASINDAKİ DIŞ TICARETIN GELIR VE FIYYAT ESNEKLIKKLERİ KAPSAMINDA EKONOMETRIK ANALIZI
}

\begin{abstract}
ÖZ
Çalışmanın amacı, Çin ile Türkiye arasındaki ticarette gelir ve fiyat etkisini analiz etmektir. Ayrıca Türkiye'nin dış ticaretinde stratejik öneme sahip bu ülke ile ticaret yapmanın, Türkiye'nin dış ticaret açı̆̆ı üzerindeki muhtemel etkilerini tartışmaktır. Dağıtılmış Otoregresif Gecikmeli Model (ARDL) ekonometrik zaman serisi yönteminin tercih edildiği çalışmada, 1998Q12018Q4 dönemine ait üç aylık veriler kullanılmıştır. Verilerin tamamı analizde logaritmik değerleri ile kullanılmıştır. Gerçekleştirilen birim kök testi sonuçları, bazı değişkenlerin düzey değerlerinde durağan olduğunu, bazılarının ise birim kök içerdiğini göstermiștir. Ancak ilk farkları alındığında hepsinin durağan hale geldiği görülmüştür. Her iki model için yapılan eşbütünleşme testleri sonucunda elde edilen $\mathrm{F}$ istatistikleri, değişkenler arasında uzun dönemli bir entegrasyon ilişkisinin olduğunu göstermiştir. Uzun dönem katsayılarının sonuçları, Türkiye'nin Çin'e yaptığı ihracatta gelir etkisinin güçlü, istatistiksel olarak anlamlı ve ekonomik beklentilerle uyumlu olduğunu göstermiştir. Öte yandan, Türkiye'nin Çin'den yaptığ 1 ithalatta hem fiyat hem de gelir etkisinin güçlü, istatiksel olarak anlamlı ve ekonomik beklentilerle uyumlu olduğu görülmüş̧ür.
\end{abstract}

Anahtar Kavramlar: Gelir ve Fiyat Esneklikleri, Dış Ticaret, ARDL Sınır Testi, Çin, Reel Efektif Döviz Kuru.

\section{INTRODUCTION}

Foreign trade balance, which is one of the important sub-items of the current account balance, is of great importance in terms of the economic stability of a country. In a country where foreign trade imbalances, especially foreign trade deficits, can experience serious problems both macroeconomically and internationally. One of the most important of these problems is that these deficits can create obstacles to direct international physical investments that will enter a country. In addition, these deficits can have negative effects on both financial and real markets and cause some macroeconomic imbalances.

Turkey adopted a free foreign trade policy in the 1980s. This outwardlooking policy has led to increased and chronic foreign trade deficits. Such foreign trade deficits are of great importance in terms of preserving economic stability and attracting international capital to the country. Therefore, the reduction of these foreign trade deficits to a minimum has been one of the primary objectives of economy managements. Based on this, the study examined income and price effectiveness in foreign trade between Turkey and China and its impact on the development of Turkey's trade deficits.

According to the Turkish Statistical Institute, China is rank as in the order of the 18th with an export figure of $\$ 2,726,571,000$ among the 20 most 
exported countries by Turkey as of 2019. As of the same year, when the total import figures made by Turkey were examined, while China was ranked 3rd with an figure of approximately $\$ 19,127,972,000$ among the 20 most imported countries.

When Table 1 is examined, as of 2013, Turkey's exports to China which accounted for $2.3 \%$ of total exports has fallen to $1.5 \%$ in 2020 . When the import figures for the same year are analyzed, this ratio, which was $9.7 \%$ as of 2013 , did not show a significant change as of 2020 and realized as $9.4 \%$. These results show that, China holds an important place in Turkey's total foreign trade volume.

When the results of foreign trade deficits were examined, as of 2013, at the foreign trade between China and Turkey, Turkey has gave an approximately $\$ 21,505,000,000$ foreign trade deficit. This ratio is seen to represent around $21,6^{\prime} \%$ of the deficit of the total foreign trade of Turkey. When the same data was examined for 2020, it was observed that Turkey's foreign trade with China was given a foreign trade deficit of approximately $\$ 20,154,000,000$. This rate was found to account for approximately $36.0 \%$ of Turkey's total foreign trade deficit.

Table 1. Foreign Trade Figures Between China and Turkey (Million \$)

\begin{tabular}{lllllll}
\hline Year & Export & $\%$ & Import & $\%$ & $\begin{array}{l}\text { The Foreign } \\
\text { Trade Deficit }\end{array}$ & $\begin{array}{l}\text { Share in } \\
\text { Total (\%) }\end{array}$ \\
\hline 2020 & 2.866 & 1,5 & 23.020 & 9,4 & -20.154 & 36,0 \\
2019 & 2.726 & 1,5 & 19.128 & 9,1 & -16.402 & 55,6 \\
2018 & 3.079 & 1,7 & 21.506 & 9,3 & -18.427 & 34,1 \\
2017 & 3.038 & 1,8 & 23.754 & 9,9 & -20.716 & 27,9 \\
2016 & 2.379 & 1,6 & 24.852 & 12,2 & -22.474 & 42,4 \\
2015 & 2.501 & 1,7 & 25.284 & 11,8 & -22.783 & 36,3 \\
2014 & 2.971 & 1,8 & 25.733 & 10,2 & -22.762 & 26,9 \\
2013 & 3.756 & 2,3 & 25.261 & 9,7 & -21.505 & 21,6 \\
\hline
\end{tabular}

Reference: Turkish Statistical Institute (TÜİK)

These rates have shown that Turkey has given a significant foreign trade deficit in foreign trade with China and these rates are increasing. In this context, the study has been built on the effect of income and price mechanism on trade between the two countries. It is thought that the results of the research will contribute to the current literature on the subject, as well as shed light on the economic management that struggles with these deficits.

The study consists of a total of four sections after the introduction section. In the first part, theoretical and conceptual analysis on the subject has been carried out. In the next section, a summary of the literature including examples of similar studies is given. After the third chapter on econometric 
application, which includes data, model and methodological infrastructure and empirical application findings, the results and recommendations are included in the fourth and final section.

Methodological infrastructure for empirical application can be summarized as follows; With the unit root test, 'the series are not stationary' null hypothesis has been tested against 'the series are stationary' alternative hypothesis (Vergil and Erdoğan, 2009, pp. 35-57). After the series appeared to be stationarity, the ARDL Boundary Test was conducted to determine the longrun cointegration relationship between variables. With this test, the null hypothesis 'there is no co-integration between the series' has been tested against the alternative hypothesis 'there is a co-integration between the series'. After the long run cointegration relationship between the series was seen, ARDL Models were established in order to reveal the short and long run relationships between the series at the final stage (Narayan and Smyth, 2004, pp. 332-342).

\section{THEORETICAL AND CONCEPTUAL FRAMEWORK}

When the Literature research including examples of similar studies is conducted, it is seen that the trade deficits in different countries have different reasons. Foremost among these are money and finance policies, external shocks (especially demand and price), liberalization of trade, economic growth, competitiveness and outward closure.

Silwall (2008) states that, changes based on global demand or price shocks and global interest rates and changes in fiscal and monetary policies of major economies may have negative effects on the macroeconomic stability of some countries. He states that, the effects of these shocks are mostly felt in asset prices, domestic interest rates, foreign trade imbalances and real economic activities. However, in the absence of a selective and appropriately ordered commercial liberalization, it is underlined that countries' liberalization of imports is another factor that may cause foreign trade deficit in order to encourage rivalry and exports. In addition, economic growth, cyclical fluctuations, foreign exchange speculation and the unexpected factors that develop outside the controls of countries are also key factors behind foreign trade deficits are known (Seyidoğlu, 2015).

The effects of exchange rates on international trade have been an interesting issue, especially in terms of developing countries economies (Sek and Har, 2014). The success of this effect, which is manifested by devaluation applications, is based on two main theoretical approaches. The first of these approaches is the BRM model developed by Bickerdike (1920). The second is the Marshall Lerner rule developed by Marshall (1923) and Lerner (1944). In the first approach, supply and demand are calculated in export and import elasticity, while the second approach calculates only export and import elasticity (Vergil and Erdoğan, 2009, p.35-57). 
Another important approach in this context is the Elasticity Approach. The Elasticity Approach, which is at the focal point of long discussions about how and how effective the changes in the real exchange rate affect the foreign trade balance, is the first theoretical approach put forward on the subject. The acceptance of exchange rate and exchange rate adjustments as the main factor and policy support instrument in ensuring external balance constitutes the core of this approach (Yaprakl1, 2010, pp.141-164). This approach, whose origins go back to the work of Bickerdike (1906-1920), focuses on how and in what direction devaluation will have an impact on the foreign trade balance. A devaluation to be implemented in any country is expected to make the country's goods cheaper by foreign countries and to make the prices of foreign goods expensive for the country. In other words, according to this approach, devaluation is expected to decrease the foreign exchange expenses by decreasing imports in a country, and increase foreign currency incomes by increasing exports. Therefore, this approach argues that devaluation will positively affect the foreign trade and current account balance by reducing foreign exchange expenditures and increasing foreign exchange revenues (Çak, 2013). The effect of devaluation on foreign trade and current account balance is parallel to the fulfillment of the Marshall-Lerner condition. Marshall-Lerner's Rule examines the effect of devaluation on external deficit. According to the Marshall Lerner's Rule, if the sum of the export good's coefficient of external demand elasticity $\left(\boldsymbol{e}_{\boldsymbol{x}}\right)$ and the domestic demand elasticity of the imported goods $\left(\boldsymbol{e}_{\boldsymbol{m}}\right)$ are greater than or equal to one, the devaluation objective may be achieved (Hepaktan, 2009, pp. 40-55).

$$
\boldsymbol{e}_{\boldsymbol{m}}+\boldsymbol{e}_{\boldsymbol{x}} \geq 1
$$

Considering that, all other conditions remain unchanged, there is a similar relationship between national income and imports, between foreign income and export growth. It is stated that the first one is discussed in the literature within the scope of import function and the second within the scope of export function. The increase in imports as a result of the increase in domestic income is a leak in terms of foreign trade. In this context, while export is data, in case of income increase, foreign trade terms may develop against the country and this may cause foreign trade deficit. On the contrary, when all other conditions are accepted as fixed, the increase in foreign income may cause foreign trade terms to change in favor of the country. The country's exports may increase and cause a possible foreign trade surplus (Yücel, 2006, pp.48-67).

\section{LITERATURE SUMMARY}

When empirical literature on foreign trade deficits is examined, it is seen that different results are obtained in the studies conducted for different countries. One of the most important reasons for this is the dependence of exports on imports, and the other is the elasticity of imported and exported goods. 
Countries, which are predominantly exporter of light industry, textile and agriculture-based products and on the other hand, are highly importer of intermediate goods and investment products, can faced high trade deficits. In addition, chronic foreign trade deficits may occur in countries where exports are highly dependent on imports.

Most of the studies in the literature investigate the price effect on exports and imports under the Marshall-Lerner condition, while the effects of income change are discussed within the framework of domestic and international income differences. It is not possible to talk about consensus in the results obtained from studies where different methods are used. While some studies emphasize the significant effect of the Marshall-Lerner condition or, in other words, price on foreign trade deficits, some studies point to the significant effect of income changes on foreign trade deficits. The summary with examples of studies conducted in both Turkey and countries outside Turkey is included in the table below.

Table 2. Literature Summary

\begin{tabular}{llll}
\hline Author(s) & Method & Period Interval & Results \\
\hline & & & $\begin{array}{l}\text { Results have shown that the } \\
\text { marshall lerner condition is } \\
\text { provided. Therefore, it has been } \\
\text { stated that the devaluations to be } \\
\text { made will have an impact on } \\
\text { foreign trade deficits }\end{array}$ \\
\hline
\end{tabular}

\begin{tabular}{|c|c|c|c|}
\hline $\begin{array}{l}\text { Bahmani } \\
\text { Oskooee and } \\
\text { Niroomand } \\
(1998)\end{array}$ & $\begin{array}{l}\text { Ordinary Least } \\
\text { Squares (OLS) } \\
\text { Method }\end{array}$ & 1960-1992 & $\begin{array}{l}\text { While income elasticities are } \\
\text { found high level in most countries, } \\
\text { the Marshall-Lemer condition has } \\
\text { been met in almost all countries }\end{array}$ \\
\hline
\end{tabular}

\begin{tabular}{|c|c|c|c|}
\hline $\begin{array}{l}\text { Hatemi and } \\
\text { Irandoust (2005) }\end{array}$ & $\begin{array}{l}\text { Panel Data } \\
\text { Method }\end{array}$ & 1960-1999 & $\begin{array}{l}\text { It has been stated that the Marshal } \\
\text { Lerner condition has not } \\
\text { materialized outside Germany }\end{array}$ \\
\hline
\end{tabular}

$\begin{array}{llll} & \text { Engle and } & \text { It was concluded that devaluation } \\ \text { Granger Co- } & \text { 1992-2006 } & \begin{array}{l}\text { It } \\ \text { integration not be effective in trade } \\ \text { (Quarterly Data) }\end{array} & \begin{array}{l}\text { deficits, since Marshall-Lerner } \\ \text { condition could not be met }\end{array}\end{array}$

$\begin{array}{lll}\text { Bahman1- } & \text { ARDL Bounds } & \text { 1980-2003 } \\ \text { Oskooee and } & \text { Testing Approach } & \text { (Quarterly Data) } \\ \text { Cheema (2009) } & \end{array}$

In the long run, a positive and significant relationship was observed between the real exchange rate and the foreign trade balance in Pakistan. 


\begin{tabular}{|c|c|c|c|}
\hline \multirow{10}{*}{ Uz (2010) } & OLS & \multirow{10}{*}{$\begin{array}{l}\text { For Switzerland is } \\
\text { 1983Q1-2007Q4, } \\
\text { For Russia } \\
\text { 1990Q1-2007Q4 } \\
\text { and For All Other } \\
\text { countries 1982Q2- } \\
\text { 2007Q4. }\end{array}$} & \multirow{10}{*}{$\begin{array}{l}\text { In the study, income and price } \\
\text { elasticities between major trading } \\
\text { partners, bilateral trade with } \\
\text { Turkey were examined. The } \\
\text { results show that the income } \\
\text { elasticity of trade in the long run is } \\
\text { high and it is not in the short run. } \\
\text { It is concluded that the Marshall } \\
\text { Lerner condition is valid only for } \\
\text { trade with Canada, USA and South } \\
\text { Korea. }\end{array}$} \\
\hline & FMOLS & & \\
\hline & ARDL & & \\
\hline & Multivariate & & \\
\hline & Maximum- & & \\
\hline & Likelihood & & \\
\hline & Procedure (JOH- & & \\
\hline & ML) & & \\
\hline & and The Vector & & \\
\hline & $\begin{array}{l}\text { Error Correction } \\
\text { (VEC) Model }\end{array}$ & & \\
\hline
\end{tabular}

Styf (2010) $\quad$ Method $\quad$ (Quarterly Data)

It has been stated that devaluation will reduce the foreign trade deficit and the Marshall-Lerner condition is realized

$\begin{array}{ll}\text { Haider, Afzal, } & \begin{array}{l}\text { Ordinary Least } \\ \text { and Riaz (2011) }\end{array} \\ & \begin{array}{l}\text { Squares (OLS) } \\ \text { Method }\end{array}\end{array}$

Yayar et al. (2013)
1995-2010

(Quarterly Data)
It has been determined that income and exchange rate changes are important determinants in bilateral trade

Ensuring the Marshall lerner condition has shown that the exchange rate is an important factor in Turkey's trade with Russia

The results of the study showed

$\begin{array}{ll}\text { Bleaney and } & \text { Fixed Effects } \\ \text { Tian (2014) } & \begin{array}{l}\text { Regression } \\ \text { method }\end{array}\end{array}$

1994-2010 that in the long-term, adevaluation implementation will improve the foreign trade balance equally and significantly for all countries

The study results, which investigated price elasticity in Jordan's exports and imports, showed that the total export and
Lila (2014)
Johansen
Cointegration Test
1980-2012 import price elasticities total was greater than one and therefore the Marshall Lerner condition was provided. This result also showed that devaluations in Jordan could have an impact on the balance of foreign trade 
Bozok, Doğan and Yüncüler (2015)
Panel Time-Series Methods

2005-2013

(Quarterly Data)

In the study, the income and price elasticities of exports to 67 countries that Turkey has made determined according to different criteria were investigated. The results obtained were found to be statistically significant in income elasticity estimation results for all country groups, and the price elasticity estimation results were found to be statistically significant only in exports to some country groups (EU27, MENA, Middle East and North African Countries)

$\begin{array}{lll}\text { Raissi and Tulin } & \begin{array}{l}\text { Panel ARDL } \\ \text { Approach }\end{array} & \text { 1990-2013 } \\ \text { (Monthly Data) }\end{array}$

Raissi and Tulin (2015)
The results show that international relative prices have an impact on exports by India
Özmen and

Karadam (2016)

FMOLS Method

1994-2013

(Monthly Data)

Exports and imports are determined by world output and domestic income with seriously high elasticity. In addition, the results showed that the external income elasticity of exports is significantly greater than the domestic income elasticity of imports

Autoregressive

Thomas (2016) Distributed Lag (ARDL) Approach
1996-2012

(Quarterly Data)

The study results showed that the long run income elasticity of service exports in India is high, while the price elasticity of service exports is statistically insignificant. In service imports, both income and price elasticity of demand were found to be statistically significant, and service imports were more affected by income than price.

The results show that tourists visiting the USA are more sensitive to changes in the real exchange rate than changes in GDP. French tourists react greatly to GDP, while British tourists react greatly to the real exchange rate 


\begin{tabular}{|c|c|c|c|}
\hline Sadok (2018) & $\begin{array}{l}\text { Ordinary Least } \\
\text { Squares (OLS) } \\
\text { Method }\end{array}$ & $2000-2015$ & $\begin{array}{l}\text { The results showed that foreign } \\
\text { exchange rates had a strong effect } \\
\text { on foreign trade in Morocco }\end{array}$ \\
\hline Sastre (2018) & $\begin{array}{l}\text { Maximum } \\
\text { Likelihood } \\
\text { Cointegration } \\
\text { Procedure (JOH- } \\
\text { ML) }\end{array}$ & - & $\begin{array}{l}\text { The results show that, the } \\
\text { devaluation to be made in the long } \\
\text { run, export and import price } \\
\text { elasticity with cross-elasticity will } \\
\text { improve the trade balance }\end{array}$ \\
\hline $\begin{array}{l}\text { Alakbarov et al. } \\
\text { (2018) }\end{array}$ & $\begin{array}{l}\text { OLS, FMOLS, } \\
\text { DOLS and CCR } \\
\text { Methods }\end{array}$ & 2001-2015 & $\begin{array}{l}\text { Research results show that the } \\
\text { income elasticity of Turkey's } \\
\text { import demand is higher than price } \\
\text { elasticity. The result also means } \\
\text { that income changes in Turkey are } \\
\text { more affected by imports than } \\
\text { prices }\end{array}$ \\
\hline
\end{tabular}

\begin{tabular}{|c|c|}
\hline $\begin{array}{l}\text { Çulha, Eren and } \\
\text { Ögüünç (2019) }\end{array}$ & $\begin{array}{l}\text { Method of } \\
\text { Kalmanfilter }\end{array}$ \\
\hline
\end{tabular}

The results show that, the income and expenditure elasticities decrease over time in total imports and in sub-components except for intermediate goods

\section{ECONOMETRIC APPLICATION}

\section{A. DATA SET AND MODEL}

1998Q1-2018Q4 period in study using quarterly data, the total export and import series were obtained from the Turkey Statistical Institute database denominated in dollars. The GDP of China and Turkey are taken in dollars from the World Bank Global Economic Monitor database. Real effective exchange rate data of Turkey were obtained from the statistics database of the Central Bank of the Republic of Turkey. Logarithmic forms of the data were used in the analyzes.

In the study, models developed by Bahmani-Oskooee and Brooks (1999) were used. In these models, the export and import series are dependent, and the real exchange rate as well as domestic and foreign income variables are accepted as independent variables. The validity of the Marshall Lerner rule and the effectiveness of domestic and external income elasticity in Turkey's trade with China have been predicted in the following equations 
Model 1; Export Demand Model

$$
\operatorname{Exp}_{t}^{T U R}=\vartheta_{0}+\vartheta_{1} R E R_{t}+\vartheta_{2} G D P_{t}^{\text {China }}+\varepsilon_{t}
$$

Model 2; Import Demand Model

$$
I m p_{t}^{T U R}=\omega_{0}+\omega_{1} R E R_{t}+\omega_{2} G D P_{t}^{T u r}+\varepsilon_{t}
$$

Where, $E_{t}$ symbolizes total goods exports to China, while $I_{t}$ shows total imports of goods from China. RER while shows Turkey's real effective exchange rate, GDP ${ }_{t}^{T U R}$ symbolizes the domestic income obtained in Turkey. $G D P_{t}^{\text {China }}$ also symbolizes the domestic income obtained in china. $\vartheta_{1}$ and $\omega_{1}$ show the exchange rate elasticity coefficients of exports and imports respectively, while $\vartheta_{2}$ ve $\omega_{2}$ show the income elasticity coefficients of exports and imports respectively. Also $\varepsilon_{t}$ indicates the error term.

The increase in the real effective exchange rate will mean an increase in value of the Turkish lira, while the decline in the real effective exchange rate means impairment in Turkish Lira (The Central Bank of Republic of Turkey, General Directorate of Statistics, 2017). Therefore, it is expected that the exchange rate coefficient of the import model $\vartheta_{1}$ will be positive $\left(\vartheta_{1}>0\right)$ in line with the economic expectations and the exchange rate coefficient of the export model $\omega_{1}$ will be negative $\left(\omega_{1}<0\right)$. However, income variables coefficients are expected to yield positive results $\left(\vartheta_{2}>0\right.$ and $\left.\omega_{2}>0\right)$, again in line with economic expectations. In addition, if $\vartheta_{1}$ and $\omega_{1}$ exchange rate elasticity coefficients is greater than one $\left(\vartheta_{1}+\omega_{1}>1\right)$, which means that the elasticity condition and therefore the Marshall-Lerner rule is also valid (Seyidoğlu, 2013).

\section{B. METHODOLOGY AND EMPIRICAL FINDINGS}

\section{Unit Root Analysis}

Macroeconomic series with heteroscedasticity in the process and do not exhibit a deterministic orientation in the long term do not have a mostly stable structure (Atgür and Altay, 2015, pp. 79-97). Working with such data containing a unit root, causes spurious regression problems in empirical analysis. For this reason, level of stationarity should be determined before make an analysis with such data.

ARDL Boundary Test approach, which does not require the same level of stationary necessity of series, has provided important advantages in econometric analysis. The most important difference of this approach from other approaches is that it allows the co-integration analysis to be carried out even if they are in the level values $(\mathrm{I}(0))$, the first differences $(\mathrm{I}(1))$ or in a mixed structure, except the second differences (I(2)) of the whole series (Özdamar, 2015). 
Augmented Dickey Fuller (ADF) (1981) and Phillips and Perron (PP) (1988) tests are unit root tests to investigate the stationarity of the series (Vergil ve Erdoğan, 2009). Considering the autoregressive and moving averages, ADF test, which includes many problems, has constant variance and unrelated errors. On the contrary, In Philips (1987) and Philips and Perron (1988) tests, there may be error terms and heteroscedasticity, including autocorrelation between them (Kızılkaya, Sofuoğlu and Karaçor, 2016, p.265). Therefore, in order to obtain accurate and reliable results, Philips-Perron (PP) unit root test was applied to all series along with ADF unit root test results are given in the table below.

Table 3. Result of Unit Root Test

\begin{tabular}{|c|c|c|c|c|c|c|}
\hline \multirow[b]{2}{*}{ Variables } & \multicolumn{3}{|c|}{ ADF (Level Value) } & \multicolumn{3}{|c|}{ PP (Level Value) } \\
\hline & Intercept & $\begin{array}{l}\text { Intercept/ } \\
\text { Trend }\end{array}$ & None & Intercept & $\begin{array}{l}\text { Intercept/ } \\
\text { Trend }\end{array}$ & None \\
\hline $\operatorname{Exp}^{\text {TUR }}$ & $-2,94 * *$ & $-1,44$ & 1,93 & $-2,29$ & $-2,05$ & 2,47 \\
\hline Imp ${ }^{\text {TUR }}$ & $-2,08$ & 0,05 & 2,34 & $-2,00$ & $-0,05$ & 2,34 \\
\hline GDP ${ }^{\text {Tur }}$ & 0,19 & $-3,14$ & 3,64 & 0,19 & $-3,20 * * *$ & 3,61 \\
\hline GDPChina & $-1,08$ & $-0,50$ & 3,88 & $-0,87$ & $-0,54$ & 7,14 \\
\hline RER & $-2,55$ & $-2,60$ & $-0,24$ & $-2,51$ & $-2,60$ & $-0,29$ \\
\hline \multirow[b]{2}{*}{ Variables } & \multicolumn{3}{|c|}{ ADF (First Difference Value) } & \multicolumn{3}{|c|}{ PP (First Difference Value) } \\
\hline & Intercept & $\begin{array}{l}\text { Intercept/ } \\
\text { Trend }\end{array}$ & None & Intercept & $\begin{array}{l}\text { Intercept/ } \\
\text { Trend }\end{array}$ & None \\
\hline $\operatorname{Exp}^{\text {TUR }}$ & $-4,73 *$ & $-8,69 *$ & $-4,11 *$ & $-12,93 *$ & $-21,31 *$ & $-11,41 *$ \\
\hline $\operatorname{Imp}^{\mathrm{TUR}}$ & $-8,43^{*}$ & $-8,91 *$ & $-7,96 *$ & $-8,50 *$ & $-8,93 *$ & $-7,94 *$ \\
\hline $\mathrm{GDP}^{\mathrm{Tur}}$ & $-8,79 *$ & $-8,77 *$ & $-3,34 *$ & $-8,78^{*}$ & $-8,77 *$ & $-7,96^{*}$ \\
\hline GDP China & $-5,12^{*}$ & $-5,21 *$ & $-1,68 *$ & $-5,18 *$ & $-5,14 *$ & $2,50 * *$ \\
\hline RER & $-9,98 *$ & $-10,16^{*}$ & $-10,04 *$ & $-10,46^{*}$ & $-11,69 *$ & $-10,53 *$ \\
\hline \multirow{2}{*}{$\begin{array}{l}\text { Significan } \\
\text { ce Level }\end{array}$} & \multicolumn{3}{|c|}{ Critical Values } & \multicolumn{3}{|c|}{ Critical Values } \\
\hline & Intercept & $\begin{array}{l}\text { Intercept/ } \\
\text { Trend }\end{array}$ & None & Intercept & $\begin{array}{l}\text { Intercept/ } \\
\text { Trend }\end{array}$ & None \\
\hline$\% 1$ & $-3,51$ & $-4,07$ & $-2,60$ & $-3,51$ & $-4,07$ & $-2,59$ \\
\hline$\% 5$ & $-2,90$ & $-3,46$ & $-1,95$ & $-2,90$ & $-3,46$ & $-1,94$ \\
\hline$\% 10$ & $-2,59$ & $-3,16$ & $-1,61$ & $-2,59$ & $-3,16$ & $-1,61$ \\
\hline
\end{tabular}

Note: $(*)$ indicate $1 \%$ significance level, $(* *)$ indicate $5 \%$ significance level and $(* * *)$ indicates $10 \%$ significance level.

The unit root test results carried out with the help of three different models showed that some variables were stationary in level values $(\mathrm{I}(0))$ and others in first difference values (I(I)). These results also show that there is a mixed stationary structure and therefore the ARDL Boundary Test approach can be applied in order to investigate the cointegration relationship between the variables in the next step. 


\section{ARDL Cointegration Test}

In the study, ARDL co-integration analysis, which will be applied to both export and import models, will be estimated with the help of the equations given below;

$$
\begin{aligned}
\Delta I m p_{t}^{T U R}=\vartheta_{0}+ & \sum_{i=1}^{n} \vartheta_{1 i} \Delta I m p_{t-1}^{T U R}+\sum_{i=0}^{n} \vartheta_{2 i} \Delta R E R_{t-i}+\sum_{i=0}^{n} \vartheta_{3 i} \Delta G D P_{t-i}^{T u r}+\vartheta_{4} I m p_{t-1}^{T U R} \\
& +\vartheta_{5} R E R_{t-1}+\vartheta_{6} G D P_{t-1}^{T u r} \\
& +\mu_{t} \\
\Delta E x p_{t}^{T U R}=\omega_{0} & +\sum_{i=1}^{m} \omega_{1 i} \Delta E x p_{t-1}^{T U R}+\sum_{i=0}^{m} \omega_{2 i} \Delta R E R_{t-i}+\sum_{i=0}^{m} \omega_{3 i} \Delta G D P_{t-i}^{\text {China }} \\
& +\omega_{4} X_{t-1}+\omega_{5} R E R_{t-1}+\omega_{6} G S H_{t-1}^{\text {China }} \\
& +\mu_{t}
\end{aligned}
$$

Equations number 3 and 4, which show the models adapted to the study, are the equations used to investigate the co-integration relationship between the stationary series of the export and import models. $\Delta$ represents the first difference of variables, while $\mathrm{n}$ and $\mathrm{m}$ symbolize the lag lengths. $I m p_{t}^{T U R}$ and $\operatorname{Exp}_{t}^{T U R}$ symbolize explanatory variables of import and export models, respectively.

The $\mathrm{F}$ value calculated after the cointegration test is compared with the table values in the study conducted by Peseran et al. (2001). If the value obtained is below the largest and smallest critical values in the table, the null hypothesis cannot be rejected and it is assumed that there is no cointegration relationship between the series. If a value is obtained between the upper and lower critical values, no decision can be made as to whether there is a cointegration relationship and alternative tests are applied. However, if the obtained statistical value is higher than the upper value, then zero hypothesis is rejected, alternative hypothesis is accepted and it is accepted that there is a cointegration relationship between the series. In this context, F statistics values obtained as a result of the cointegration test are given in the table below. 
Table 4. ARDL Boundary Test Statistics (F Test and Critical Boundary Values)

\begin{tabular}{lllll}
\hline Models & Variables $(\mathrm{k})$ & F statistics & $\begin{array}{l}\text { Critical values } \\
(\% 1)\end{array}$ & $\begin{array}{l}\text { Critical values } \\
(\% 5)\end{array}$ \\
\hline Export & 2 & \multirow{2}{*}{$5,79^{*}$} & $\begin{array}{l}\mathrm{I}(0)-\mathrm{I}(1) \\
4,13-5\end{array}$ & $\begin{array}{l}\mathrm{I}(0)-\mathrm{I}(1) \\
3,1-3,87\end{array}$ \\
& & & $\mathrm{I}(0)-\mathrm{I}(1)$ & $\mathrm{I}(0)-\mathrm{I}(1)$ \\
Import & 2 & $7.98^{*}$ & $4,13-5$ & $3,1-3,87$
\end{tabular}

Note: $\left(^{*}\right)$ indicates $1 \%$ significance level.

The results of the ARDL Boundary Test showed that $\mathrm{F}$ statistical values from both models were higher than the upper value of the critical table values of Peseran et al. (2001). In addition, the values obtained were statistically significant. As a result, in both models, the null hypothesis is rejected, and the alternative hypothesis indicating that there is a cointegration relationship between the series is accepted.

\section{ARDL Model Estimations}

After being seen the cointegration relationship between the variables, the ARDL model estimation, in which the lag lengths were determined to be independent from each other and different from the cointegration test, was estimated by the following equations as adapted to the study

$$
\begin{aligned}
& I m p_{t}^{T U R}=\vartheta_{0}+\sum_{i=1}^{k} \vartheta_{1 i} I m p_{t-1}^{T U R}+\sum_{i=0}^{r} \vartheta_{2 i} R E R_{t-i}+\sum_{i=0}^{p} \vartheta_{3 i} G D P_{t-1}^{T u r} \\
& +\mu_{t}
\end{aligned}
$$

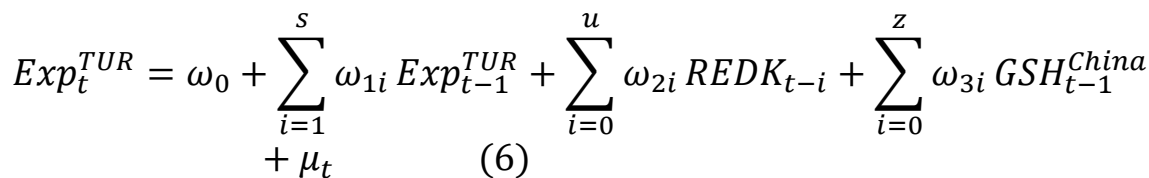

Variable $\operatorname{Imp} p_{t}^{T U R}$ in the equation no 5 indicates the dependent variable consisting of the import series, while $\mathrm{k}, \mathrm{r}$ and $\mathrm{p}$ indicate the lag lengths. Equation 6 shows the export model, while $\operatorname{Exp}_{t}^{T U R}$ symbolizes the dependent variable consisting of the export series, while $\mathrm{s}, \mathrm{u}$ and $\mathrm{z}$ symbolize the lag lengths. Model estimation results are given in below. 
Table 5. ARDL Model Estimations Results

\begin{tabular}{|c|c|c|c|c|}
\hline \multirow[b]{2}{*}{ Variables } & \multicolumn{2}{|c|}{ Export Model $(1,0,0)$} & \multicolumn{2}{|c|}{ Import Model $(5,3,0)$} \\
\hline & Coefficient & t-Statistic & Coefficient & t-Statistic \\
\hline $\operatorname{Exp}^{\mathrm{TUR}}(-1)$ & $0.57 *$ & 6.65 & - & - \\
\hline GDP China & $0.67 *$ & 4.60 & - & - \\
\hline RER & 0.16 & 0.53 & - & - \\
\hline Dumexp & $0.19 *$ & 3.75 & - & - \\
\hline C & $-2.22 *$ & -3.01 & - & - \\
\hline $\operatorname{Imp}^{\mathrm{TUR}}(-1)$ & - & - & $0.53^{*}$ & 5.30 \\
\hline $\operatorname{Imp}^{\mathrm{TUR}}(-2)$ & - & - & 0.03 & 0.29 \\
\hline $\operatorname{Imp}^{\mathrm{TUR}}(-3)$ & - & - & -0.14 & -1.26 \\
\hline $\operatorname{Imp}^{\mathrm{TUR}}(-4)$ & - & - & $0.58^{*}$ & 5.29 \\
\hline $\operatorname{Imp}^{\mathrm{TUR}}(-5)$ & - & - & $-0.26^{*}$ & -3.33 \\
\hline GDP $P^{\text {Tur }}$ & - & - & $2.05^{*}$ & 4.82 \\
\hline $\mathrm{GDP}^{\text {Tur }}(-1)$ & - & - & -0.41 & -0.76 \\
\hline $\mathrm{GDP}^{\mathrm{Tur}}(-2)$ & - & - & $0.90 * * *$ & 1.68 \\
\hline $\mathrm{GDP}^{\text {Tur }}(-3)$ & - & - & $-1.64 *$ & -3.57 \\
\hline RER & - & - & $0.77^{*}$ & 5.39 \\
\hline Dumimp & - & - & $0.07 *$ & 4.26 \\
\hline C & - & - & $-4.78 *$ & -4.51 \\
\hline $\begin{array}{l}\text { Diagnostic Test } \\
\text { Stat. }\end{array}$ & & Coefficient & & Coefficient \\
\hline R-squared & & 0,960 & & 0,995 \\
\hline Adjusted R-squared & & 0,958 & & 0,994 \\
\hline Serial Correlation & & $0,53(0,47)$ & & $0,84(0,36)$ \\
\hline Normality Test & & $1,21(0,55)$ & & $2,61(0,27)$ \\
\hline Heteroskedasticity & & $7,71(0,10)$ & & $14,52(0,21)$ \\
\hline $\operatorname{Prob}($ F-statistic) & & 0,000 & & 0,000 \\
\hline
\end{tabular}

Note: Symbols $(*)$ and $(* * *)$ represent $1 \%$ and $10 \%$ significance levels, respectively. Values in parentheses indicate probability levels. Using the Schwarz information criterion, the maximum lag length was chosen as 8 (Quarterly data). 
The export model is estimated as ARDL $(1,0,0)$ according to the appropriate lag lengths. The export variable in the model was found to be statistically significant and in line with economic prospects at the first lag. The foreign income variable was also found to be statistically significant and in line with economic prospects. The exchange rate variable was found to be statistically insignificant. In addition, due to structural break in the model, the dummy variable that was subsequently added to the model was found statistically significant at $1 \%$ level.

In the import model which is estimated as ARDL (5.3.0), import variable was found to be compatible with the economic prospects in all lags except for the second, third and fifth lag, while was statistically significant. National income variable, on the other hand, was found statistically significant and to be compatible with economic prospects, both at level value and in the second lag. In addition, the dummy variable which is added to model later due to the structural break in the model and the real effective exchange rate variable were also found compatible with economic prospects and statistically significant.

In order to understand that the results obtained from the model are reliable, diagnostic tests were applied. All the test results realized were statistically over $0.05 \%$ and it was observed that there were no diagnostic problems in both models. Breusch-Godfrey test showed that there was no serial correlation problem in models. Breusch-Pagan-Godfrey test results showed that there was no heteroscedasticity problem in both models. Finally, Jarque-Bera test results showed that the error terms in the model have a normal distribution.

CUSUM and CUSUMS of Squares Tests, which were calculated with the aim of testing the stability of the parameters of the import and export models, showed that both models had a structural change. For this reason, it was decided to add one dummy variable to both models to represent structural breaks. These dummy variables were added externally to the model based on the frequency ranges out of the limit of the CUSUM and CUSUM of Squares Test graph given below to reflect the positive or negative effects (structural breaks) on the variables for the break periods. The CUSUM and CUSUM of Squares graphs, which are known as parameter stability tests before and after the dummy variable included in the model for these break periods, are given below. 
Figure 1. ARDL CUSUM and CUSUM-SQ Graphs (Export Model)

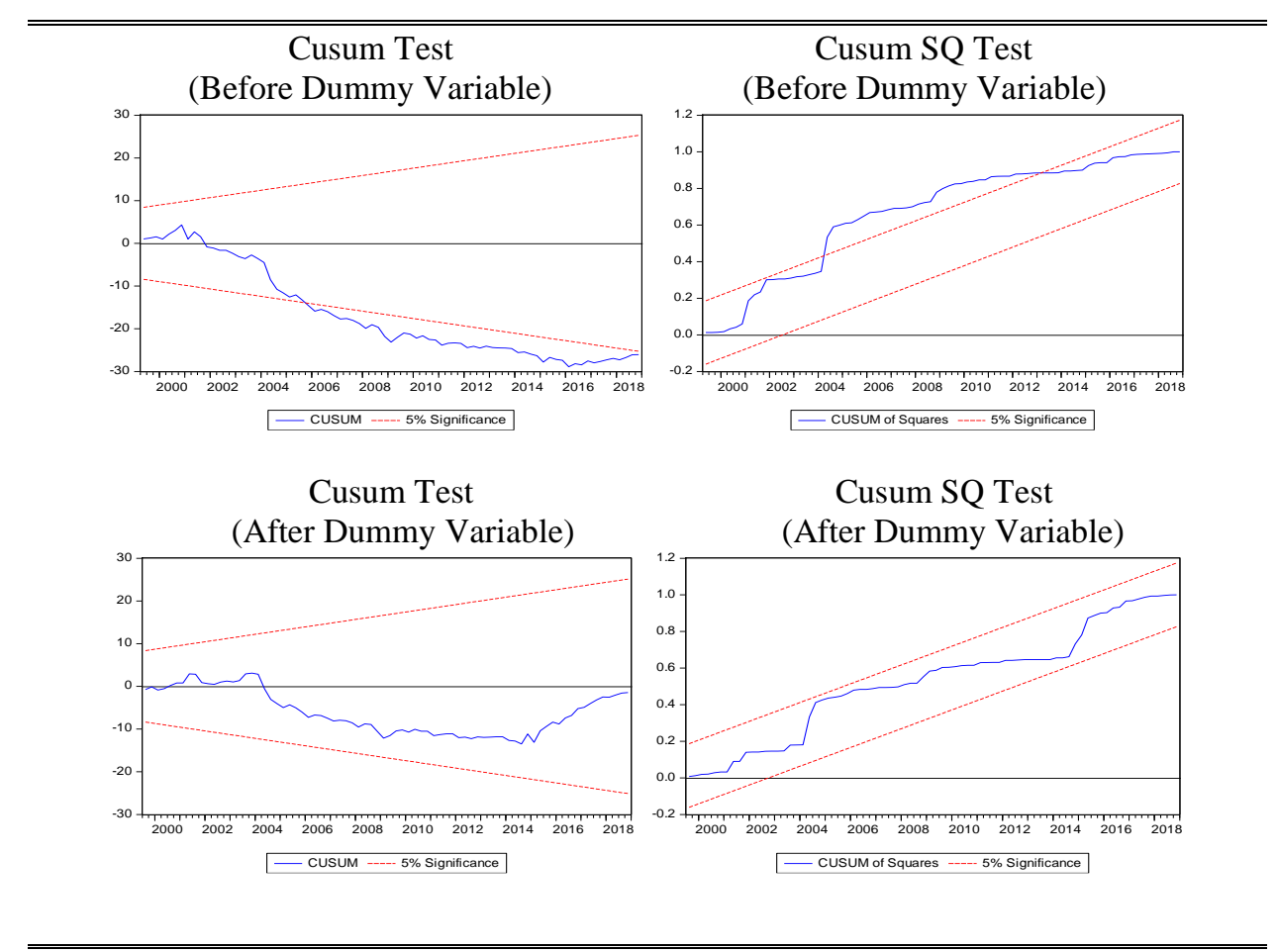


Figure 2. ARDL CUSUM and CUSUM-SQ Graphs (Import Model)

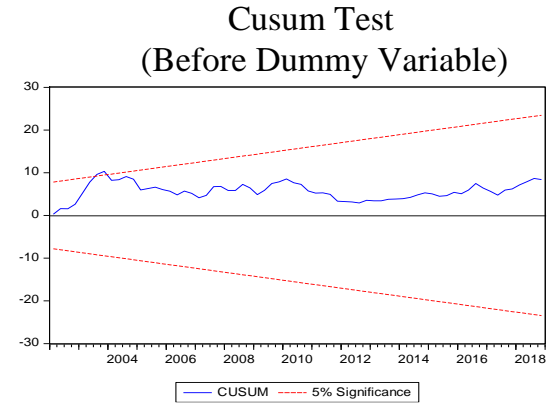

Cusum Test

(After Dummy Variable)

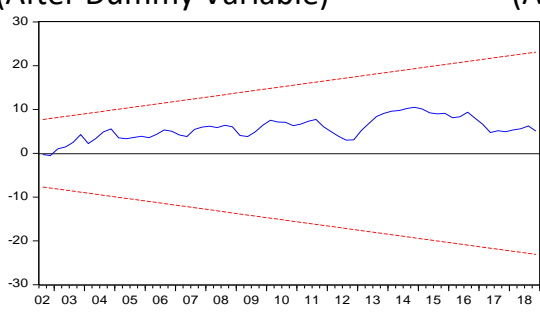

_ CUSUM ---. $5 \%$ Significance

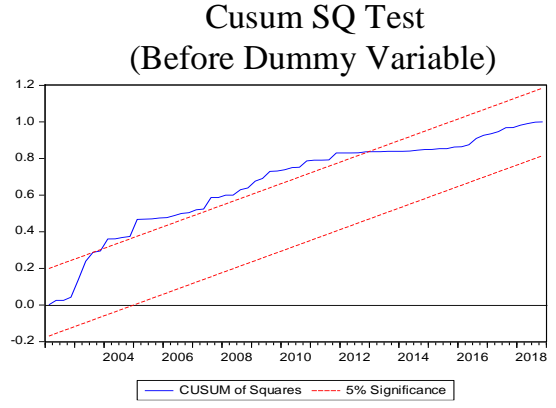

Cusum SQ Test

(After Dummy Variable)

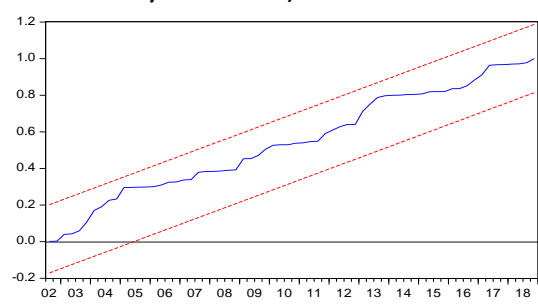

- CUSUM of Squares..$--5 \%$ Significance

After the dummy variables included in the models, the residuals of both models remained within the boundaries, and the parameters of the model displayed a stable structure.

\section{Long-Term Coefficients and Error Correction Model}

After model estimations, short run relationships between series are investigated by establishing Error Correction Models. The Error Correction Term (ECT) obtained from the model estimates and the residues of these estimates shows how much the short-term deviations approach the balance in the next period (Gülmez, 2015, p. 149). Error Correction Models, which use the first differences of the series, show the short-term relationships between the variables and are compatible with the study, are estimated with the help of the following equations.

$$
\begin{aligned}
& I m p_{t}^{T U R}=\boldsymbol{\alpha}_{\mathbf{0}}+\sum_{i=1}^{v} \boldsymbol{\alpha}_{1 i} \Delta I m p_{t-1}^{T U R}+\sum_{i=0}^{y} \boldsymbol{\alpha}_{2 i} \Delta R E R_{t-i}+\sum_{i=0}^{l} \boldsymbol{\alpha}_{3 i} \Delta G D P_{t-1}^{T u r} \\
& +\emptyset E C T_{t-1}+\mu_{t}
\end{aligned}
$$




$$
\begin{gathered}
\operatorname{Exp}_{t}^{T U R}=\boldsymbol{\beta}_{0}+\sum_{\substack{i=1\\
}}^{d} \boldsymbol{\beta}_{1 i} \Delta E x p_{t-1}^{T U R}+\sum_{\substack{i=0\\
}}^{u} \boldsymbol{\beta}_{2 i} \Delta R E D K_{t-1}+\mu_{t}+\sum_{i=0}^{c} \boldsymbol{\beta}_{3 i} \Delta G S H_{t-1}^{\text {China }} \\
+\partial E C T_{t-1}
\end{gathered}
$$

The $\Delta I m p_{t}^{T U R}$ and $\Delta E x p_{t}^{T U R}$ variables in the models symbolize the first differences of the import and export series, the (ECT) variable Error Correction Term and $\emptyset$ and $\partial$ symbolize the Error Correction Term coefficients. Error Correction Coefficients are expected to be statistically significant and negative at the same time. Based on this, the Estimated Error Correction Model and long run coefficient results are given in the table below.

\begin{tabular}{|c|c|c|c|c|}
\hline \multirow[t]{2}{*}{ Variables } & \multicolumn{2}{|c|}{ Export Model $(1,0,0)$} & \multicolumn{2}{|c|}{ Import Model $(5,3,0)$} \\
\hline & Coefficient & $\mathrm{t}$-Statistic & Coefficient & t-Statistic \\
\hline RER & 0.37 & 0.53 & $2.97 *$ & 16.49 \\
\hline $\mathrm{GDP}^{\mathrm{Tur}}$ & - & - & $3.46^{*}$ & 7.73 \\
\hline Dumimp & - & - & $0,26 *$ & 6,12 \\
\hline GDP China & $1.57 *$ & 17.56 & - & - \\
\hline Dumexp & $0,45^{*}$ & 5,12 & & \\
\hline \multirow[t]{2}{*}{$C$} & $-5.19 *$ & -3.62 & $-18.56 *$ & -15.10 \\
\hline & \multicolumn{4}{|c|}{ ARDL Error Correction Model Estimation Results } \\
\hline GDP $^{\text {China }}$ & $1.47 * * *$ & 1.82 & - & - \\
\hline Dumexp & $0.19 *$ & 3.24 & - & - \\
\hline $\operatorname{Imp}^{\mathrm{TUR}}(-1)$ & - & - & $-0.22 * *$ & -2.61 \\
\hline $\operatorname{Imp}^{\text {TUR }}(-2)$ & - & - & $-0.19 * *$ & -2.19 \\
\hline $\operatorname{Imp}^{\mathrm{TUR}}(-3)$ & - & - & $-0.34 *$ & -4.21 \\
\hline $\operatorname{Imp}^{\mathrm{TUR}}(-4)$ & - & - & $0.25 *$ & 3.51 \\
\hline $\mathrm{GDP}^{\mathrm{Tur}}$ & - & - & $2.05^{*}$ & 5.46 \\
\hline $\operatorname{GDP}^{\operatorname{Tur}}(-1)$ & - & - & $0.76^{* * *}$ & 1.91 \\
\hline $\mathrm{GDP}^{\mathrm{Tur}}(-2)$ & - & - & $1.67 *$ & 4.18 \\
\hline RER & 0.20 & 0.47 & $0.73^{*}$ & 5.63 \\
\hline Dumimp & - & - & $0.05 * *$ & 2.01 \\
\hline $\operatorname{ECT}(-1)$ & $-0.40 *$ & -4.59 & $-0.27 *$ & -7.04 \\
\hline
\end{tabular}

Table 6. ARDL Models Long Run Elasticity Coefficients Estimation Results

Note: Symbols $(*),(* *)$ and $(* * *)$ represent $1 \%, 5 \%$ and $10 \%$ significance levels, respectively.

Short run results of the error correction model for the export model have shown that the exchange rate elasticity coefficient is statistically insignificant. This also meaning that the real effective exchange rate is not to be effective on Turkey's export to China. On the other hand, for import model, the elasticity coefficient of real effective exchange rate variable is found to be compatible with the economic expectations and statistically significant at the level of $1 \%$ in 
the short run. In other words, this result meaning that, a $\% 1$ increase in the real effective exchange rates in Turkey has increase its imports from china by $0,73 \%$ in the short run.

The elasticity coefficients of income variables of Turkey and China is found to be statistically significant. These results are the evidence that, in the short run, the incomes obtained in Turkey and China have an impact on imports and exports of Turkey respectively. In other words, according to the short run results, a $1 \%$ increase in incomes of Turkey has increase its imports from china by $2,05 \%$ while a $1 \%$ increase in incomes of China has increase Turkey's export to china by $1,47 \%$. However, in the short run, dummy variables included externally in models representing structural changes detected in both export and import models is also found statistically significant at $1 \%$ and $5 \%$, respectively.

Total export and total import models error correction terms (ECT) were found negative and statistically significant at $1 \%$ level in accordance with economic expectations. This results shows that $40 \%$ of the shocks occurring in the short run in the export model and $27 \%$ in the import model came to balance in the next period.

The long run elasticity coefficients of income variables of Turkey and China is found to be statistically significant at the level of $1 \%$ for both models. These results are the evidence that in the long run, the incomes obtained in Turkey and China has demonstrated a strong and pozitive impact on imports and exports of Turkey respectively. In other words, according to the long run results, a $1 \%$ increase in incomes of Turkey is increase its imports from china by $3,46 \%$ while a $1 \%$ increase in incomes of China is increase Turkey's export to china by $1,57 \%$. However, in the long run, dummy variables included externally in models representing structural changes detected in both export and import models is also found statistically significant at the $1 \%$ level.

When the long run real effective exchange rate elasticity coefficient results were analyzed for both models, it was seen that the coefficient in question was statistically insignificant for the export model. The real effective exchange rate elasticity coefficient of the import model was found to be statistically significant. In addition, the result gave a result compatible with economic prospects in terms of coefficient sign. This means that, a $1 \%$ increase in the real effective exchange rate will result in a strong $2.97 \%$ increase in Turkey's imports. In addition, these results have shown that the Marshall Lerner rule has not materialized in the bilateral trade. The reason for this is that the export model exchange rate elasticity coefficient was statistically insignificant. 


\section{CONCLUSION}

The results of the long-run elasticity coefficients obtained in the study showed that a $1 \%$ increase in Turkey's revenue increased imports from China by $3.46 \%$. China's $1 \%$ increase in revenue while Turkey's exports to China increase by $1.57 \%$. This result, which is statistically significant and compatible with economic expectations, supports the similar study results in the literatüre (Bahmani Oskooee and Niroomand, 1998; Haider, Afzal, and Riaz, 2011; Özmen and Karadam, 2016).

When the long run real effective exchange rate elasticity coefficient results were analyzed, it was seen that the coefficient was statistically insignificant for the export model. The results of the import model showed that an increase of $1 \%$ in the exchange rate would lead to a strong $2.97 \%$ increase in Turkey's imports. These results have shown that the Marshall Lerner rule has not materialized in the bilateral trade. The reason for this is that the export model exchange rate elasticity coefficient was statistically insignificant. This results also supports the similar study results in the literature (Hatemi and Irandoust, 2005; Peker, 2008).

When the results of foreign trade deficits were examined, as of 2019, it was observed that Turkey's foreign trade with China was given a foreign trade deficit of approximately $\$ 16,401,401,000$. This rate was found to account for approximately $55.6 \%$ of Turkey's total foreign trade deficit. These rates have shown that Turkey has given a significant foreign trade deficit in foreign trade with China and these rates are increasing. Given the results from long-run import model coefficients, it has been observed that economic growth and exchange rate declines in Turkey significantly increase Turkey's foreign trade deficits. In this context, it is thought that domestic production should increase with the incentives to be provided to computing machines, electronic units, audio and video pointing devices, toys, television buyers and different agricultural products, which stand out in the imports from China. It is thought that this increase in production will have a positive effect on foreign trade deficits. Secondly, in exports to a large market such as China, the implementation of various incentive mechanisms can increase the competitive power of exporters by providing price advantage. It is thought that this will increase exports to China and positively affect trade deficits. In addition, considering the results obtained from the study, it is thought that the smoothing of Central Bank's pressing in exchange rates will play an important role in ensuring both the macroeconomic and foreign trade balance. 


\section{REFERENCES}

Akdoğan, İ. U. (2010). Bilateral trade elasticities of Turkey. International Journal of Applied Economics, 7(1), 28-46.

Alakbarov, N., Özkaya, M. H., Gündüz, M. \& Şaşmaz, M. Ü. (2018). Türkiye'nin ithalat talep fonksiyonunun yapısal kırılmalı eşbütünleşme analizi ile tahmini. Abant İzzet Baysal Üniversitesi Sosyal Bilimler Enstitüsü Dergisi, 18(4), 67-84.

Andersson, A. and Styf, S. (2010). How does a depreciation in the exchange rate affect trade over time?. (Bachelor's thesis within economics), Sweden: Jönköping University.

Arize, A. C. (1994). Cointegration test of a long-run relation between the real effective exchange rate and the trade balance. International Economic Journal, 8(3), 1-9.

Atgür, M. and Altay, N. O. (2015). Enflasyon hedeflemesi sürecinde para talebi istikrarının ARDL modeli yaklaşımı ile analizi: Türkiye ve Endonezya örneği. Eskişehir Osmangazi Üniversitesi İI.I.B.F. Dergisi, 10(1), 79- 97.

Bleaney, M. and Tian, M. (2014). Classifying exchange rate regimes by regression methods. University of Nottingham Discussion Papers in Economics, 14(2), 1-40.

Bozok, İ., Doğan, B. Ş. \& Yüncüler, Ç. (2015). Estimating income and price elasticity of Turkish exports with heterogeneous panel time-series methods. Central Bank of the Republic of Turkey Working Paper, 15(26), $1-23$.

Çak, M. (2013). Türkiye'de cari açık. İstanbul: Beşir Kitabevi.

Çulha, O. Y., Eren, O. \& Öğünç, F. (2019). Import demand function for Turkey. Central Bank Review, 19, 9-19.

Gülmez, A. (2015). Türkiye'de dış finansman kaynakları ekonomik büyüme ilişkisi: ARDL sınır testi yaklaşımı. Ekonomik ve Sosyal Araştırmalar Dergisi, 11(2), 139-152.

Haider, J., Afzal, M., \& Riaz, F. (2011). Estimation of import and export demand functions using bilateral trade data: The case of Pakistan. PeerReviewed and Open Access Journal, 6(3), 40-53.

Hatemi J. A. and Irandoust, M. (2005). Bilateral trade elasticities: Sweden versus her trade partners. American Review of Political Economy, 3(2), $38-50$.

Hepaktan, C. E. (2008, Şubat). Türkiye’nin dönüşüm sürecinde dış ticaret politikaları, 2. Ulusal İktisat Kongresi, İzmir. 
Kızılkaya, O., Sofuoğlu, E. and Karaçor, Z. (2016). Ekonomik büyüme, enerji tüketimi ve çevre kirliliği analizi: Türkiye örneği. Kırıkkale Üniversitesi Sosyal Bilimler Dergisi, 6(2), 256-269.

Lila, Z. M. A. (2014). Price and income elasticities of international trade: Case of Jordan. International Journal of Economics and Finance, 6(10), 250258.

Narayan, P. K.and Smyth, R. (2004). Temporal causality and the dynamics of exports, human capital and real income in China. International Journal of Applied Economics. 1(1), 24-45.

Ongan, S., Işik, C., \& Özdemir, D. (2017). The effects of real exchange rates and income on international tourism demand for the USA from some European Union countries, economies, MDPI, Open Access Journal, 5(4), $1-11$.

Oskooee, M. B. and Niroomand, F. (1998). Long-run price elasticities and the Marshall-Lerner Condition revised. Economics Letters, 61(1), 101-109.

Oskooee, M. B. and Cheema, J. (2009). Short-run and long-run effects of currency depreciation on the bilateral trade balance between Pakistan and her major trading partners. Journal of Economic Development, 34(1), 1946.

Özmen, E. and Karadam, D. Y. (2016). Structural change in Turkish external trade: Evidence from BEC sectors. Ekonomik Yaklaşım, 27(100), 207-221.

Peker, O. (2008). Reel döviz kurunun ticaret dengesi üzerindeki etkileri: Türkiye örneği. İktisadi ve İdari Bilimler Dergisi, 22(2), 33-43.

Raissi, M. and Tulin V. (2015). Price and income elasticity of Indian exports-the role of supply-side bottlenecks. IMF Working Paper, 15(161), 1-16.

Sadok, H. (2018). The effect of exchange rates on trade balance: An empirical study of Morocco. Journal of Business and Economics Review, 3(1), 1-10.

Sastre, L. (2018). Marshall-Lerner Condition and the balance of payments constrained growth: The Spanish case. Review of Economics \& Finance, (13), 29-38.

Sek, S. K.and Har, W. M. (2014). Testing for Marshall-Lerner condition: Bilateral trades between Malaysia and trading partners. Journal of Advanced Management Science, 2(1), 23-28.

Seyidoğlu, H. (2015). Uluslararası iktisat teori politika ve uygulama (21.bs). İstanbul: Güzem Can Yayınları. 
Thomas, M. P. (2016). Estimation of income and price elasticities of India's trade in services: Evidence from Post-WTO period. South Asia Economic Journal, 17(1), 27-45.

Vergil, H. and Erdoğan, S. (2009). Döviz kuru-ticaret dengesi ilişkisi: Türkiye örneği. Zonguldak Karaelmas Üniversitesi Sosyal Bilimler Dergisi, 5(9), $35-57$.

Yapraklı, S. (2010). Türkiye'de esnek döviz kuru rejimi altında dış açıkların belirleyicileri: Sınır testi yaklaşımı. Ankara Üniversitesi S.B.F. Dergisi, 65(4), 141-164.

Yayar, R. and Birol, Y. E., Demir, Y. (2013). Türkiye'nin ihracat ve ithalat talep fonksiyonlarının Rusya ile dış ticareti bağlamında analizi, Internatınal Conference on Eurasian Economies, St. Petersburg: Russia.

Yücel, F. (2006). D1ş ticaretin belirleyicileri üzerine teorik bir yaklaşım Sosyoekonomi Dergisi, 15(2), 48-67. 
